\title{
Development and Design of G+20 Residential Structure by Using Advance Tools At Palghar
}

\author{
Mr.Deepak Bhurkud ${ }^{1}$, Mr.Ritesh Patil ${ }^{2}$, Mr.Suresh Suthar ${ }^{3}$, Mr.Omkar Borkar ${ }^{4}$, Mr. Shreeshail \\ Heggond $^{5}$
}

${ }^{1234}$ UG Students, Department of Civil Engineering, St John College of Engineering \& Management, Palghar
${ }^{5}$ Assistant Professor,Department of Civil Engineering, St John College of Engineering \& Management, Palghar

Received on: 30 April, 2021, Revised on: 24 May, 2021, Published on: 26 May, 2021

\begin{abstract}
Due to growing population and less availability of land, multi-storey buildings are constructed which can serve many people in limited area. The main objective of this project is to analyse and design a $(G+20)$ multi-storeyed building using STAAD Pro. The project aims to give proper awareness to right designing and detailing of the building. First of all, the planning is done using AutoCAD. The design involves load calculations manually and the structure is analysed using STAAD Pro. The code refers for this project are NBC, IS 456-2000, SP16.The concrete mix used in this project is M30.The steel strength for all members are of grade Fe415. For analysing the structure, the loads are very important which are calculated using IS 875. The LIMIT STATE METHOD of design has been adopted. Manual design is a difficult process and consumes more time. Our project purpose is to give a complete experience in the field of design and to gain the knowledge in a practical way.
\end{abstract}

Keywords- Development and Design of Tall Building Autocad, STAADPRO Connect Edition, Advanced Concrete Design, Revit.

\section{I -INTRODUCTION}

$\mathbf{I}_{\mathrm{n}}$ every aspect of human civilization, we needed structures to live. The structures should be built in an efficient manner so that it can serve people and save money. In simple words, the building means an empty surrounded by walls and roofs, in order to give shelter for human beings. In early times humans have lived in caves to protect themselves from wild animals, rain etc. Then, humans developed and built their homes using timbers and lived. Nowadays the recent homes are developed into individual and multi-storey buildings. Buildings are the necessary indicator of social progress of the county. At current situation, many new techniques have been developed for constructions. So, that the buildings are built economically and quickly to fulfil the needs of the people. A building frame is a threedimensional structure which consists of column, beams and slabs. Because of growing population, high rise buildings are coming into demand. Buildings constitute a part of the definition of civilizations, a way of life advanced by the people. The buildings should be constructed for human requirements and not for earning money. Buildings are built in different sizes, shapes and functions. STAAD - PRO was born giant. It is the most popular software use now-a-days. Basically, it is performing design works. There are four steps using STAAD PRO to reach the goal.

\section{II- OBJECTIVES}

1. The main objective is to plan a residential building $(\mathrm{G}+20)$ and to ensure that the structure is safe against all possible loading condition 


\section{International Journal of Innovations in Engineering and Science, www.ijies.net}

and to fulfill the function for which design is done. The objective is to plan a residential building $(\mathrm{G}+20)$ by considering building by laws.

2. The objective is to design and analysis of the $\mathrm{G}+20$ building by using advance tools.

3. To analyze forces, stress, strain, deflection, shear force and bending moment for a G+20 structural system.

4. To design the building against the effect of seismic forces or wind force to make the

5. structure earthquake resistant and stable against wind pressure.

6. To get the knowledge on parameters structural elements like slab, beams, columns, foundation in the design.

7. safety requirements are fulfilled for the structure such that it is able to serve its purpose with economy.

\section{III- METHODOLOGY}

\section{Softwares used}

\section{AutoCAD:}

Drafting of the centre line wall plan on the basis of architectural plan is done by using Auto-CAD 2017. The file is then saved with file format.dfx which can be then imported in STADD PRO using structural wizard function in STADD PRO.

\section{STAAD Pro Connect Edition:}

STADD-PRO 2016 software has been thoroughly tested, validated and recognized internationally by several organization and is well suited for the analysis of the building system. Geometrical, dimensions member properties and member node connectivity, including eccentricities are modelled in the analysis problems. Variation in material grade, if present, is also considered. After preliminary sizing of various structural members on the basis of architectural drawings, a computer model of structure frame of building is generated for carrying out computer analysis for the effects of vertical and lateral loads that are likely to be imposed on the structure.

\section{STAAD Advanced Concrete Design (RCDC):}

With STAAD Advanced Concrete Design, you can design a variety of concrete elements, such as beams, columns, and walls in an automated and interactive workflow. There are options to optimize or analyse beams, columns, and walls for gravity and lateral loads to quickly obtain safe and economical designs. You will gain full control of your designs by setting a collection of carefully considered parameters, from minimum and maximum reinforcing ratios, bar spacings, bar sizes, shear bar or link preference and many more. Designs can be driven by arrangements created by the application or prescribed by the designer. Check for code compliance using an envelope of beam and column design forces or automatically create load combinations. The application is also intelligent enough to understand geometric continuity between levels and across supports for column and beam design consideration respectively, making a smooth transition of bar patterns and sizes as you move between floors or across supports. Using STAAD Advanced Concrete Design you can design nontraditional and custom shapes. The application allows you to control concrete beam, wall, and column designs including $\mathrm{L}, \mathrm{T}$, and $\mathrm{C}$ shapes. Create and check irregular bar layouts including stirrups and links using a broad range of material and design properties. Account for continuity in column stacks and beam lines when determining appropriate reinforcing layout.

\section{Details Of $\mathbf{G + 2 0}$ Residential Building:}

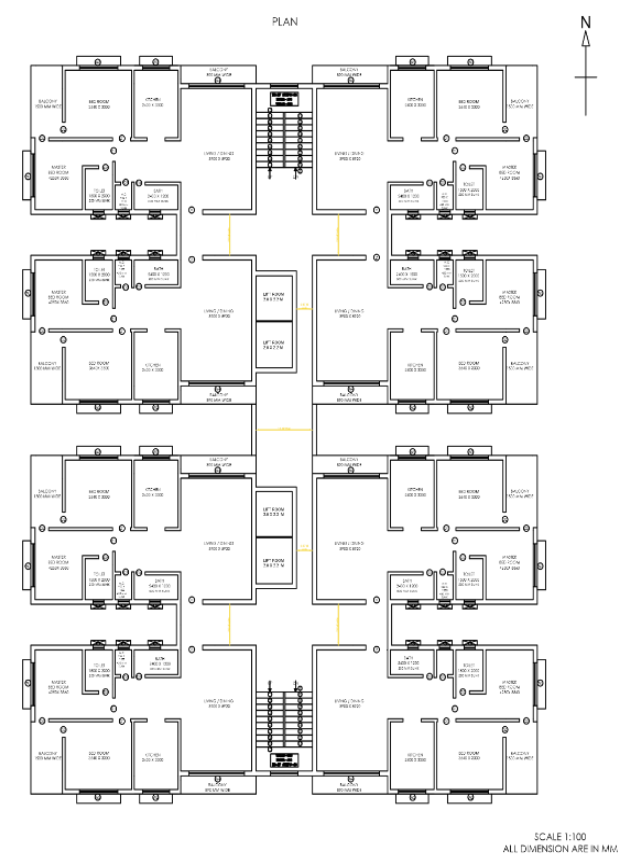

Fig 1-G+20 Residential Building Plan

3. Stages In Structural Design By Using Staad Pro Connect Edition:

- Positioning and Orientation of Columns

Positioning of Beams

Spanning of S labs 
Table no: 1

\begin{tabular}{|c|c|c|}
\hline Sr.no & Structure & Details \\
\hline 1 & Building type & $\begin{array}{l}\text { RCC residential } \\
\text { building }\end{array}$ \\
\hline 2 & Number of storied & $\mathrm{G}+20$ \\
\hline 3 & $\begin{array}{c}\text { Overall building } \\
\text { height }\end{array}$ & $66 \mathrm{~m}$ \\
\hline 4 & Plinth Area & $908 \mathrm{~m}^{2}$ \\
\hline 5 & Foundation type & Raft footing \\
\hline 6 & Foundation depth & $400 \mathrm{~mm}$ \\
\hline 7 & Soil type & $\begin{array}{l}\text { Medium soft } \\
\text { soil }\end{array}$ \\
\hline 8 & Floor to floor height & $3 \mathrm{~m}$ \\
\hline 9 & $\begin{array}{l}\text { External Wall } \\
\text { thickness }\end{array}$ & $300 \mathrm{~mm}$ \\
\hline 10 & $\begin{array}{c}\text { Internal wall } \\
\text { thickness }\end{array}$ & $\begin{array}{c}230 \mathrm{~mm} \text { and } \\
150 \mathrm{~mm}\end{array}$ \\
\hline 11 & Live load & $3.5 \mathrm{KN} / \mathrm{m}^{2}$ \\
\hline 12 & Floor finish load & $1 \mathrm{KN} / \mathrm{m}^{2}$ \\
\hline 13 & Wind velocity & $40 \mathrm{M} / \mathrm{S}$ \\
\hline 14 & Earthquake zone & Zone 3 \\
\hline 15 & $\begin{array}{l}\text { Live load on terrace } \\
\text { slab }\end{array}$ & $30 \mathrm{KN} / \mathrm{m}^{2}$ \\
\hline 16 & $\begin{array}{c}\text { Number of Water } \\
\text { tank }\end{array}$ & 4 \\
\hline 17 & Water tank height & 3 \\
\hline 18 & Concrete grade & M30, M35 \\
\hline 19 & Reinforcement grade & Fe500 \\
\hline 20 & Unit weight of RCC & $25 \mathrm{KN} / \mathrm{m}^{3}$ \\
\hline 21 & $\begin{array}{l}\text { Unit weight of } \\
\text { masonry }\end{array}$ & $20 \mathrm{KN} / \mathrm{m}^{3}$ \\
\hline
\end{tabular}

\section{- Positioning \& Operation Of Columns}

1. Columns should preferable be located at or near the corner of a building and at the intersections of beam /walls

2. Select the position of columns so as reduce bending moment in beam.

3. A void large span of beam.
4. A void large center to center distance between columns.

5. Column on property line.

6. Avoid projection of column outside wall.

7. Orient the column so that the depth of column is contained in major plain of bending or is perpendicular to the major axis of bending.

\section{- Positioning Of Beams}

1. Beams shall, normally, be provided under the walls or below a heavy concentrated load to avoid this load directly coming on slab.

2. Avoid large spacing of beams from deflection and cracking criteria.

\section{Spanning Of Slabs}

1. Slab normally act as a one-way slab when the aspect ratio $\mathrm{Ly} / \mathrm{Lx}<2$.

2. A two - way slab having aspect ratio $\mathrm{Ly} / \mathrm{Lx}<2$ is generally economical compare to one -way slab

3. Spanning of slab is also decided by necessity of continuity to adjacent slab.

\section{Orientation \& Calculation Of Joint Co- Ordinates:}

- The joint calculated and oriented considering the axis in which it is to be noted.

- The joints considered \& noted in $\mathrm{X}, \mathrm{Y}$ direction respectively.

\section{Member Incidence:}

- After's the joints are obtained the members are connected from node to node

- The floor to floor height is kept 3.0M and the y Co-ordinate change from floor to floor

- Colum are obtained by joining the first and second floor

- The $2^{\text {nd }}$ floor is repeated in y direction by trans repeat command

\section{$>$ Defining Material:}

- The concrete is defined by using this command. For e.g.: Command: DEFINE MATERIAL START ISOTROPIC CONCRETE: E

2.17185e+007, POISSON 0.17, DENSITY 23.5616, ALPHA le-005 DAMP 0.

\section{$>$ Member Property Incidence:}

- The thickness of columns and beams are defined by this command

- $\quad$ For e.g. command :912916 PRIS YD 1.2 ZD 0.23 


\section{International Journal of Innovations in Engineering and Science, www.ijies.net}

\section{$>$ Assigning Supports:}

- This is done by decrease the load on the structure

- Command use to release moment: UNIT MMS NEWTON MEMBER RELEASE

- Floor to floor members are defined

\section{$>$ Calculation Of Loads:}

- Dead load: In this the self-weight of each beam \& columns is calculated including the floor finish considering density.

As per IS 875 part I in this the member load is also considered

E.g.: DEAD LOAD, MEMBER LOAD

- Live load: in this live load is adopted per various units of the building such as balcony, passages, rooms etc.... as per IS 875 part 2

$>$ Beam Design:

- Beams are design for flexure shear and torsion

- For all these forces all active beam loading is pre-scanned to identify the critical load case at different sections of the beams

\section{$>$ Column Design:}

- columns are designed for axial moments at the ends

$>$ Load Combination:

- In this factor of safety is considered using various combinations of load

- Following are the combinations considered

$>$ Path for these: GENERAL...LOADS.... LOADS...AND DEFINITIONS...LOAD CASE DETAIL... $\quad$ ADD...LOAD COMBINATIONS .... CLOSE

\section{$>$ Perform Analysis:}

- To do analysis first we need to add the command: ANALYSIS... PERFORM ANALYSIS

- This allow the user to specify the instruction for the type of analysis to be performed using the STAAD- pro

$>$ Run Analysis:

- The analysis is performed using the ANALYZE menu in the modelling mode

- Select the run analysis option to perform analysis/ design
- The dialog box displays the status of the analysis process. if an error occurs during the analysis the dialog box displays the error massage.

- View Output File:

It will invoke the STAAD viewer with the analysis result presented in a textual format

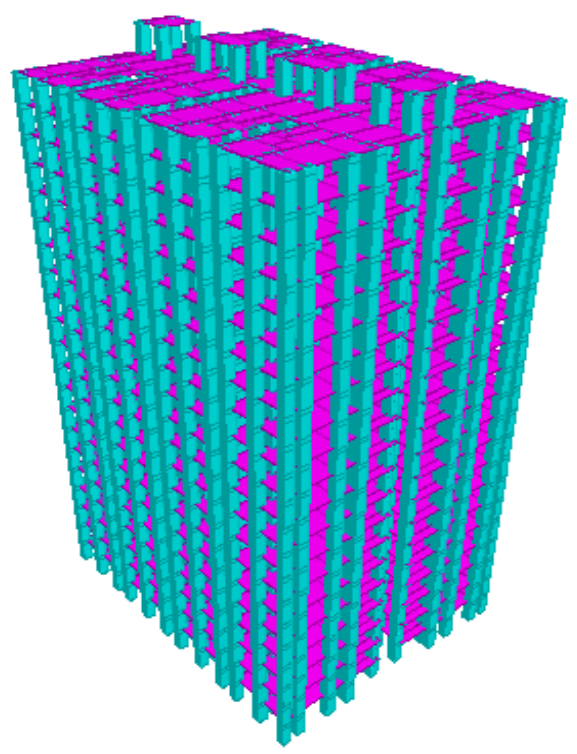

Fig 2-3D Rendering Veiw

\section{Influences of Forces}

A building has to perform to perform many functions satisfactorily. Amongst these functions are the utility of the building for intended use and occupancy, Structural safety fire safety and compliance with hygienic, Sanitation, ventilation and daylight standard. From the structural safety point of view loading criteria plays very important role while designing any structure. Before designing is being started minimum design, load which have to assume for dead load, imposed load, wind load, and other external load, the structure would be required to bear. Following are the four important loads for which any type of structure needs to be Design:

1. Dead load

2. Imposed load

3. Wind load

4. Earthquake load 
International Journal of Innovations in Engineering and Science, www.ijies.net

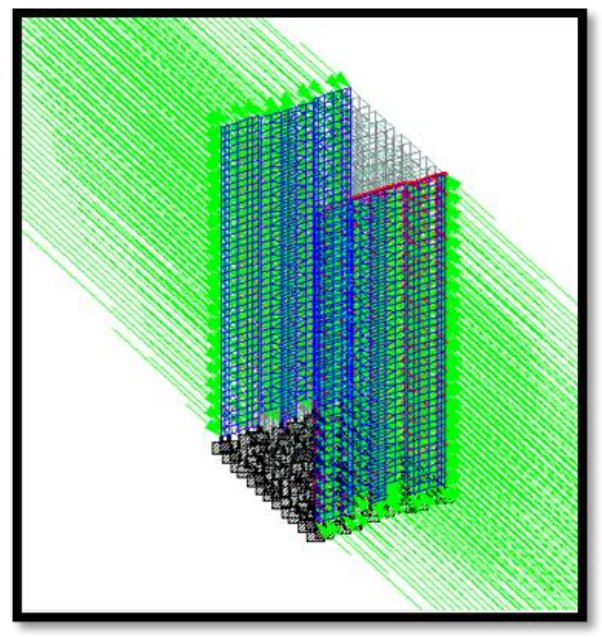

Fig 3-Wind load Diagram.

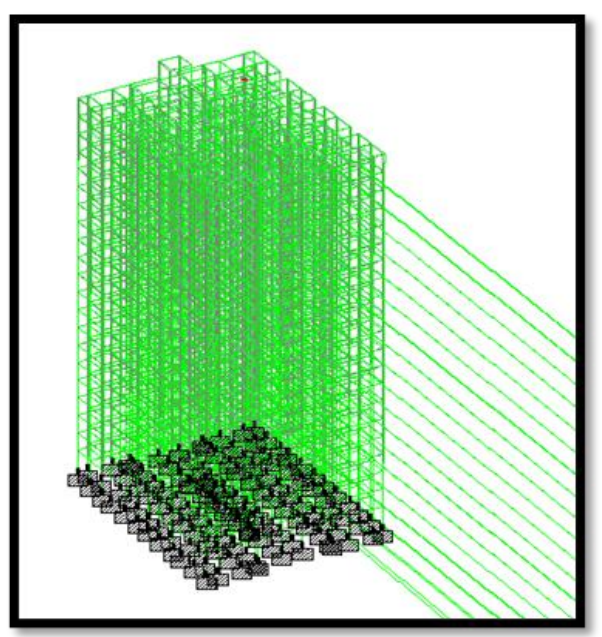

Fig 4- Earthquake loading Diagram.

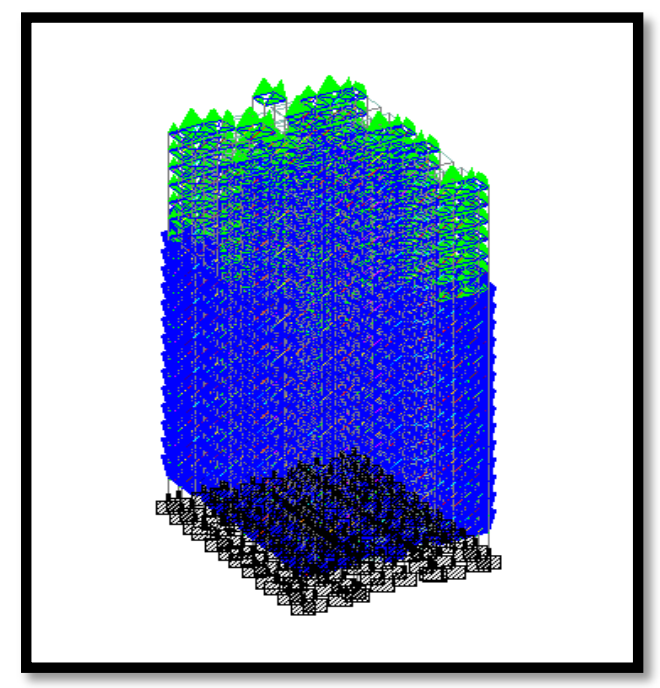

Fig 5-Live loading Diagram.

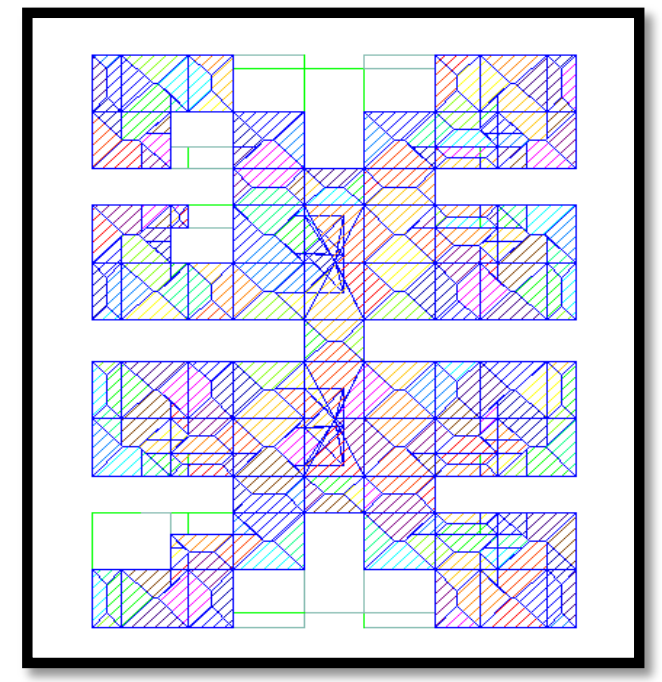

Fig 6-Live loading Diagram for Slab.

\section{Load combinations:}

Load combination for Static analysis:

-1.5(DL + IL)

-1.2(DL + IL $\pm \mathrm{EL})$

-1.5(DL $\pm \mathrm{EL})$

- 0.9 DL $\pm 1.5 \mathrm{EL}$

Load combination for For dynamic analysis:

- DL +LL

- DL+WL

- $\mathrm{DL}+0.8 \mathrm{LL}+0.8 \mathrm{WL}$

6. Steel \& Concrete Design Results:

\begin{tabular}{|c|c|c|c|c|c|}
\hline Member & Type & $\begin{array}{c}\text { Groun } \\
\text { d to } 5^{\text {th }} \\
\text { floor } \\
{[\mathrm{MM}]}\end{array}$ & $\begin{array}{l}6^{\text {th }} \text { to } \\
10^{\text {th }} \\
\text { floor } \\
{[\mathrm{MM}]}\end{array}$ & $\begin{array}{l}11^{\text {th }} \\
\text { floor } \\
\text { to } 15^{\text {th }} \\
\text { floor } \\
{[\mathrm{MM}]}\end{array}$ & $\begin{array}{c}16^{\text {th }} \\
\text { floor to } \\
20^{\text {th }} \\
\text { floor } \\
{[\mathrm{MM}]}\end{array}$ \\
\hline Column & $\begin{array}{c}\text { Primar } \\
\mathrm{y}\end{array}$ & $\begin{array}{c}850 X \\
950\end{array}$ & $\begin{array}{c}750 X \\
850\end{array}$ & $\begin{array}{c}650 X \\
750\end{array}$ & $\begin{array}{c}650 X \\
750\end{array}$ \\
\hline & $\begin{array}{c}\text { Secon } \\
\text { dary }\end{array}$ & $\begin{array}{c}800 X \\
850\end{array}$ & $\begin{array}{c}700 X \\
750\end{array}$ & $\begin{array}{c}600 X \\
650\end{array}$ & $\begin{array}{c}600 X \\
650\end{array}$ \\
\hline Beam & $\begin{array}{c}\text { Primar } \\
\mathrm{y}\end{array}$ & $\begin{array}{c}750 X \\
850\end{array}$ & $\begin{array}{c}600 X \\
700\end{array}$ & $\begin{array}{c}500 \times \\
600\end{array}$ & $\begin{array}{c}400 X \\
450\end{array}$ \\
\hline & $\begin{array}{c}\text { secon } \\
\text { dary }\end{array}$ & $\begin{array}{c}600 X \\
750\end{array}$ & $\begin{array}{c}500 X \\
600\end{array}$ & $\begin{array}{c}450 X \\
550\end{array}$ & $\begin{array}{c}400 X \\
500\end{array}$ \\
\hline & $\begin{array}{c}\text { Tertiar } \\
y\end{array}$ & $\begin{array}{c}400 X \\
600\end{array}$ & $\begin{array}{c}400 X \\
600\end{array}$ & $\begin{array}{c}400 X \\
600\end{array}$ & $\begin{array}{c}350 \mathrm{X} \\
500\end{array}$ \\
\hline Slab & & \multicolumn{4}{|c|}{$150 \mathrm{~mm}$} \\
\hline Raft footing & $1^{\text {st }}$ step & \multicolumn{4}{|c|}{$4900 \times 4800 \times 400$} \\
\hline & $2^{\text {nd }}$ Step & \multicolumn{4}{|c|}{$4050 \times 3950 \times 850$} \\
\hline & $3^{\text {rd }}$ Step & \multicolumn{4}{|c|}{$2200 \times 2100 \times 575$} \\
\hline
\end{tabular}

For showing Design Result we consider single element. 
Vol. 6, No. 4, 2021, PP. 01 - 07

International Journal of Innovations in Engineering and Science, www.ijies.net

\begin{tabular}{|c|c|c|c|c|c|c|}
\hline Elements & $\begin{array}{l}\text { Size } \\
(\mathrm{mm})\end{array}$ & $\begin{array}{l}\text { Bending } \\
\text { moment } \\
(\mathrm{Kn}-\mathrm{m})\end{array}$ & $\begin{array}{l}\text { Shear } \\
\text { force } \\
(\mathrm{kn})\end{array}$ & Top r/f & Bottom $r / f$ & Stirrup's link \\
\hline Column & $850 \times 950$ & 4.540 & 3.317 & $\begin{array}{c}12- \\
25 \mathrm{~mm} \phi \\
+ \\
14-12 \mathrm{~mm} \phi\end{array}$ & - & $\begin{array}{c}8 \mathrm{~mm} \phi @ 50 \mathrm{~mm} \\
\mathrm{c} / \mathrm{c}+8 \mathrm{~mm} \phi @ \\
175 \mathrm{~mm} \mathrm{c} / \mathrm{c}\end{array}$ \\
\hline Beam & $750 \times 850$ & 11.41 & 25.41 & $\begin{array}{c}7- \\
20 \mathrm{~mm} \phi\end{array}$ & $7-20 \mathrm{~mm} \phi$ & $\begin{array}{c}\text { 2L - 8mm } \phi \\
@ 120 \mathrm{~mm} \mathrm{c/c}\end{array}$ \\
\hline Slab & 150 & 0.467 & 0.164 & $\begin{array}{c}8 \phi @ \\
140 \mathrm{~mm}\end{array}$ & $\begin{array}{c}8 \phi @ \\
140 \mathrm{~mm}\end{array}$ & $8 \phi @ 300 \mathrm{~mm}$ \\
\hline \multirow{3}{*}{ Raft Footing } & $\begin{array}{c}\text { 1. } 4900 \times 4800 \\
\times 400\end{array}$ & 4309.6 & 1386.9 & $16 @ 100$ & $1.16 @ 110$ & 1. $2-10$ \\
\hline & $\begin{array}{c}2.4050 \times 3950 \\
\times 850\end{array}$ & 4309.6 & 1386.9 & & 2.20@110 & 2. 3-10 \\
\hline & $\begin{array}{c}3.2200 \times 2100 \\
\times 575\end{array}$ & 4309.6 & 1386.9 & & 3.20@115 & 3. $2-10$ \\
\hline
\end{tabular}

Table no: 3
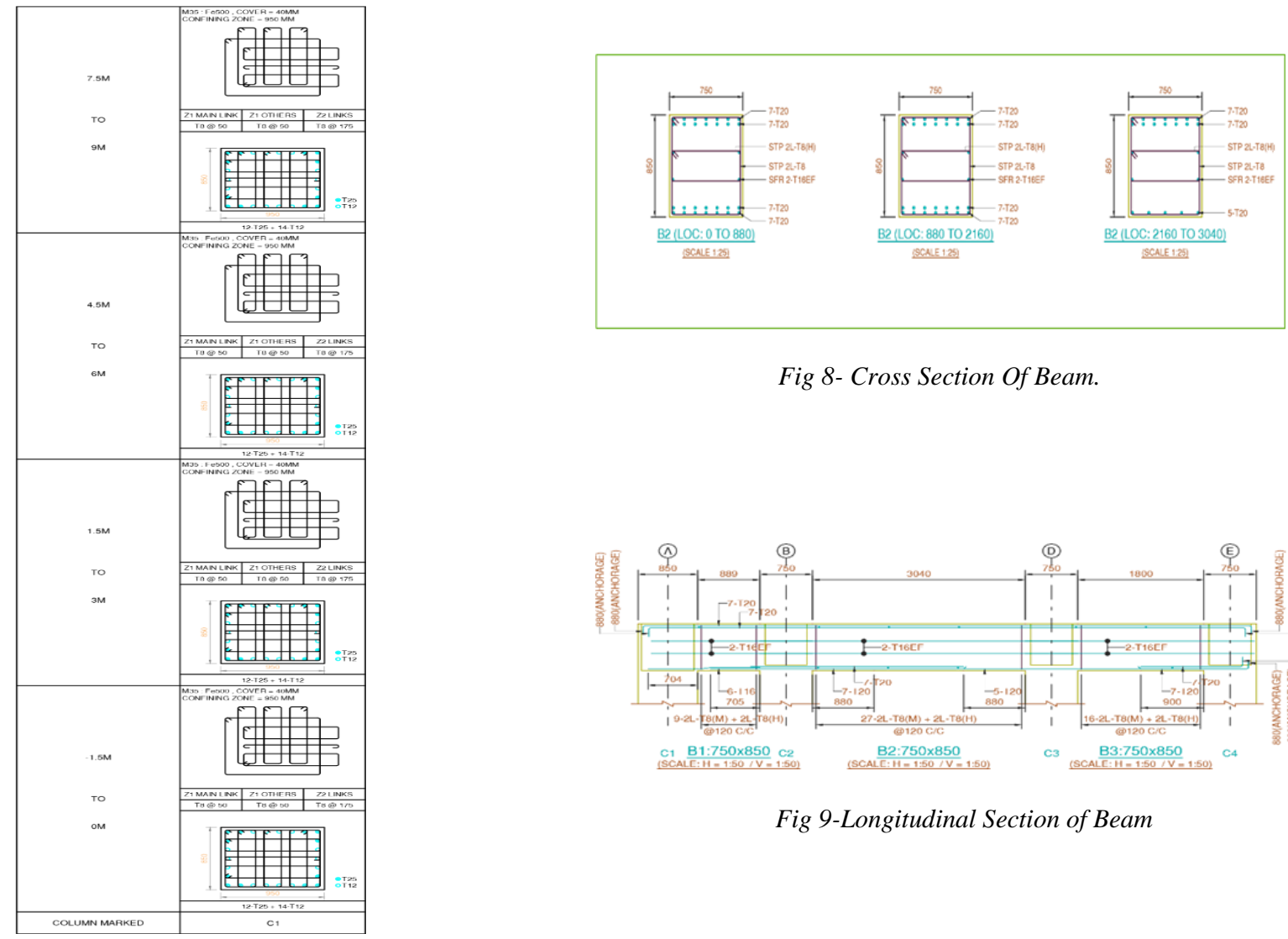

Fig 8- Cross Section Of Beam.

Fig 7-Cross section of column c1

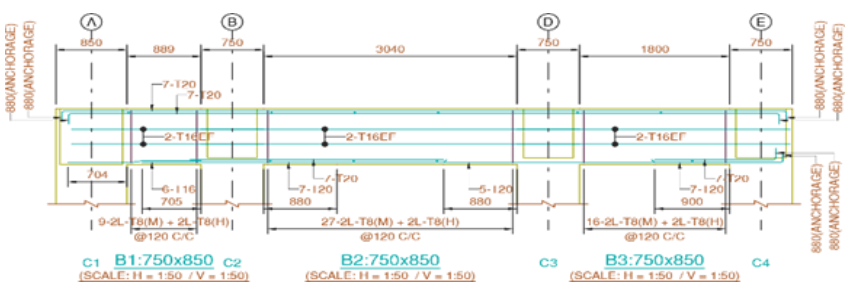

Fig 9-Longitudinal Section of Beam 


\section{International Journal of Innovations in Engineering and Science, www.ijies.net}

\section{IV- CONCLUSION}

It can be clearly observed that when a 20- storey high rise structure with same beam and column size is analysed and designed for static and dynamic loads:

1. The top beam of the structure requires less Reinforcement. Hence it reveals that more reinforcement is required in static analysis than dynamic analysis

2. Deflection and shear bending is more in dynamic analysis compare static analysis

3. In lower beams more reinforcement is required for dynamic loads compared to static loads.

4. For columns, area of steel and percentage of steel is always greater for dynamic load

5. By using staad pro software time is consumed and work is reduced.

6. All details of each and every member are obtained by using staad pro software.

7. The wind load combinations are more than Earthquake load combinations in Bending moment and shear force.

8. Area of steel in column is slightly greater in wind load combinations as compare to an earthquake load combination.

9. In structural member it is required to rearrangement of reinforcement for practical considerations.

10. It is not possible to show each and every member of details that is reinforcement, so it is required to create a grouping of members and provide reinforcement details.

\section{REFERENCES}

[1] Murty C.V.R. and Jain. S. K "A Review of IS-1893- 1984 Provisions on seismic Design of Buildings". The Indian concrete journal, Nov.1994. Sarkar P. Agrawal, $R$ and Menon,D. "Design of beam, columns joints under Seismic loadings" A review,Journal of structural engineering SERC, Vol.33. No.6. Feb.2007.

[2] Reddell R. and Lira, J.C.D.L. "Seismic analysis and design" Current practice and Future trends. Eleventh World Conference on earthquake Engineering Mexico. BIS1893, Criteria for Earthquake resistant design of structures-Part-1, General Provisions and Buildings,Bureau of Indian Standards, New Delhi -2002.

[3] IS-456 -2000 "Indian standard of code and practice for plain and reinforced concrete" Bureau of Indian Standards, New Delhi -2000.

[4] IS-875-1987."Indian standard code of practice for structural safety loadings standards" Part-1, 2 Bureau of Indian Standards, New Delhi.

[5] SP-16-1980- Design Aids for Reinforced concrete to IS4561978-Bureau of Indian Standards, New Delhi.

[6] Agarwal Pankaj and Shrikhande Manish "Earthquake resistant design of structure" PHI, Learning Pvt. Ltd. NewDelhi-2010.

[7] Rai. Durgesh. C. Hemant. B. Kaushik, Jain.Sudhir. K." A case for use of dynamic analysis in designing for earthquake forces",- Department of Civil engineering, IIT Kanpur-India.

[8] Mr. A. P. Patill, Mr. A. A. Choudhari2 , Mr. P.A. Mudhole3, Mr. V. V. Patole4, Ms. A. D.Dange5, Ms. S. K. Chendake6 Design \&Analysis of Multi Storeyed Building $(G+10)$ B yUsing Stadd Pro V8i (Series 4)

[9] D.Ramya, A.V.S.Sai Kumar "Comparative Study on Design and Analysis of Multi-storeyed Building $(G+10)$ By STAAD.Pro and Etabs Software's."IJESRT, ISSN:22779655 (I2OR), (October, 2015),

[10] Mital N. Desai, Prof. Roshni John "Comparative Study of Multi-Storey Building with Different Base Isolators.", IJIRSET (An ISO 3297: 2007 Certified Organization) Vol. 4, Issue 8, and ISSN (Online):2319-8753, ISSN (Print): 2347-6710, (August 2015). 